\title{
Penerapan Good Corporate Governance, Komitmen Organisasi, Gaya Kepemimpinan Transformasional dan Kinerja Karyawan Lembaga Perkreditan Desa
}

\author{
Ni Luh Putu Diah Cantika Wibawa ${ }^{1}$ \\ Fakultas Ekonomi dan Bisnis \\ Universitas Udayana, Indonesia
}

\author{
Ni Made Dwi Ratnadi \\ Fakultas Ekonomi dan Bisnis \\ Universitas Udayana, Indonesia
}

Surel : cantikawibawa29@gmail.com

\section{ABSTRAK}

Tujuan penelitian ini untuk mengetahui pengaruh Good Corporate Governance, komitmen organisasi, gaya kepemimpinan pada kinerja lembaga karyawan perkreditan desa. Populasi dalam penelitian ini adalah semua LPD yang ada di Kabupaten Badung yang berjumlah 122. Teknik analisis yang digunakan yaitu regresi linier berganda. Berdasarkan kriteria yang ditetapkan maka sampel diambil sebanyak 55 LPD di Kabupaten Badung. Hasil penelitian ini menunjukan bahwa Good Corporate Governance, komitmen organisasi dan gaya kepemimpinan transformasional berpengaruh positif pada kinerja karyawan LPD di Kabupaten Badung.

Kata Kunci: Good Corporate Governance; Komitmen Organisasi; Gaya Kepemimpinan; Kinerja Karyawan.

\section{Implementation of Good Corporate Governance, Organizational Commitment, Transformational Leadership Style and Employee Performance of LPD Institutions}

ABSTRACT
The purpose of this study was to determine the effect of Good Corporate
Governance, organizational commitment, leadership style on the
performance of rural credit employee institutions. The population in
this study were 122 LPDs in Badung Regency. The analysis technique
used was multiple linear regression. Based on the established criteria, 55
LPD samples were taken in Badung Regency. The results of this study
indicate that good corporate governance, organizational commitment
and transformational leadership style have a positive effect on the
performance of LPD employees in Badung Regency.
Keywords: Good Corporate Governance; Organizational
Commitment; Leadership Style; Employee
Performance.

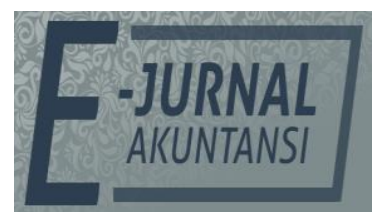

e-ISSN 2302-8556

Vol. 31 No. 3

Denpasar, Maret 2021 Hal. 591-601

DOI:

10.24843/EJA.2021.v31.i03.p06

PENGUTIPAN:

Wibawa, N. L.P.D.C., \& Ratnadi, N.M.D. (2021).

Penerapan Good Corporate

Governance, Komitmen Organisasi, Gaya Kepemimpinan

Transformasional dan Kinerja Karyawan Lembaga Perkreditan Desa. E-Jurnal Akuntansi, 31(3), 591-601

RIWAYAT ARTIKEL: Artikel Masuk:

24 Juli 2020 Artikel Diterima: 19 Februari 2021

Artikel dapat diakses : https://ojs.unud.ac.id/index.php/Akuntansi/index 


\section{PENDAHULUAN}

LPD di Kabupaten Badung memiliki tingkat perkembangan dan tingkat perputaran dana yang cukup besar. Menurut data Badan Pusat Statistika Provinsi Bali tahun 2016, di Kabupaten Badung terdapat 122 LPD yang tersebar di 6 kecamatan. Dari 122 LPD di Kabupaten Badung hanya 83 LPD yang masuk kategori sehat. Sedangkan 27 LPD kategori cukup sehat, 9 LPD kurang sehat dan 3 LPD dinyatakan tidak sehat/sakit. LPD yang dinyatakan sakit ini antara lain LPD Desa Adat Kapal (Mengwi), LPD Desa Adat Kerta Bujangga (Mengwi), dan LPD Desa Adat Abiansemal (Abiansemal). Penerapan good corporate governance, komitmen organisasi, dan gaya kepemimpinan transformasional pada kinerja karyawan lembaga perkreditan desa (lpd). (https:// bali.bps.go.id/)

Suatu kasus yang menjadi sorotan LPD di Kabupaten Badung adalah kasus dari LPD Desa Adat Kapal yang mengalami kerugian hingga Rp 10 Miliar lebih. Pemerintah Kabupaten Badung, Bali, segera mengevaluasi 122 LPD yang aktif beroprasi tersebar disejumlah desa adat yang ada di daerah itu. Upaya ini dilakukan agar pemerintah mengetahui audit internal dan eksternal dimasingmasing LPD terkait ada tidaknya kolap pengelolaan dana tersebut. Permasalahan kolapnya dana nasabah mencapai Rp10 miliar yang terjadi di LPD desa adat Kapal, dikarenakan tidak baiknya pengelolaan dana nasabah oleh pihak LPD.

Pemerintah Kabupaten Badung, terus berupaya melakukan pembinaan terhadap 122 LPD di wilayahnya dan bahkan guna meningkatkan kualitas LPD, pemkab setempat akan memberikan modal tambahan. Syaratnya LPD sehat, namun masih kekurangan dana. Pemberian penguatan modal harus memperhatikan kesehatan serta pengurus yang mengatur manajemen LPD tersebut. LPD dalam kategori kurang sehat yang disebabkan karena kurangnya modal, namun manajemennya bagus maka perlu suntikan dana. Oleh karena itu tata kelola manajemen yang baik begitu penting bagi keadaan LPD. Prinsip GCG diharapkan dapat meningkatkan kinerja LPD di Kabupaten Badung.

Definisi good corporate governance (tata kelola perusahaan yang baik) menurut Organizational for Economic Co-operation and Development (OECD) yaitu suatu sistem yang mengatur dan mengendalikan perusahaan baik hubungan antara pemegang saham, pengurus (pengelola) perusahaan, pihak kreditur, pemerintahan, karyawan serta para pemegang kepentingan intern dan ekstern lainnya yang berkaitan dengan hak-hak dan kewajiban mereka. Tata kelola perusahaan yang baik atau good corporate governance merupakan pedoman atau bisa digunakan sebagai form ula untuk menciptakan pedoman bagi pengelola perusahaan dalam mengelola manajemen perusahaan yang baik dengan memperhatikan kepentingan stakeholders (stakeholders dilingkungan LPD adalah kramadesa, pemerintah, pengelola dan masyarakat). Pengelolaan lembaga berdasarkan prinsip GCG pada dasarnya merupakan upaya untuk menjadikan GCG sebagai kaidah dan pedoman bagi pengelolaan lembaga dalam mengelola manajemen lembaga. Good corporate governance yang baik dapat memberikan rangsangan bagi board dan manajemen untuk mencapai tujuan yang merupakan kepentingan perusahaan dan pemegang saham harus memfasilitasi pengawasan yang efektif sehingga mendorong perusahaan menggunakan sumber daya yang lebih efisien (Surya \& Yustiavandana, 2006). Menurut Andriyanto (2013) Good Government Governance terbukti mampu memengaruhi kinerja manajerial secara 
positif signifikan. Kinerja manajerial yang lebih baik akan terjamin dengan diterapkannya prinsip-prinsip Good Government Governance danadanya dukungan dari semua pihak. Good Government Governance merupakan instrumen pokok entitas guna mencapai kualitas kinerja yang baik.

Penerapan good corporate governance dapat membuat LPD lebih bertanggungjawab dalam mengambil keputusan karena adanya arahan yang jelas bagi LPD sehingga dampaknya akan meningkatkan nilai LPD itu sendiri (Dewi, 2014). Penerapan good corporate governance dalam meningkatkan kinerja LPD akan semakin baik dengan adanya suatu komitmen organisasional. Menurut Robbins \& Judge (2007) mendefinisikan komitmen sebagai keadaan dimana adanya keinginan untuk mempertahankan keanggotaanya dalam organisasi tempatnya bekerja dengan mengikuti semua tujuan organisasinya dan memihak organisasi tersebut. Adanya keinginan untuk mencapai tujuan yang telah ditetapkan oleh organisasi menunjukkan jika adanya komitmen organisasi yang besar dalam diri seseorang (Wiratno, 2013). Keberhasilan penerapan good governance diduga tidak dapat tercapai tanpa dukungan komitmen dalam berorganisasi. Karena implementasi good corporate governance memerlukan komitmen organisasional dari semua pihak agar menghasilkan kinerja Sehingga dengan adanya komitmen organisasi dalam pengelolahaan LPD maka penerapan good corporate governance akan mampu meningkatkan kinerja yang dihasilkan (Ristanti, 2014).

Komitmen adalah tingkat kepercayaan dan penerimaan karyawan pada organisasi untuk berkeinginan tetap dalam organisasi demi mencapai tujuan organisasi. Menurut Shore \& Wayne (1993) mengatakan komitmen organisasi memiliki hubungan dengan tingkat kehadiran, karyawan dengan komitmen organisasi tinggi lebih termotivasi untuk ikut serta dalam proses organisasi karena mereka memiliki keinginan untuk membantu organisasi dalam mencapai tujuannya.

Komitmen organisasi merupakan dorongan dari dalam individu untuk melakukan sesuatu agar dapat menunjang keberhasilan organisasi sesuai dengan tujuan yang telah ditetapkan dan lebih mengutamakan kepentingan organisasi. Karyawan atau anggota organisasi yang memiliki komitmen yang kuat akan bekerja dengan maksimal agar organisasi tempat mereka bekerja dapat mencapai keberhasilan bekerja dengan maksimal. Karim \& Rehman (2012) mengatakan komitmen organisasi sebagai keyakinan teguh dalam pengakuan dari karyawan mengenai tujuan atau prinsip-prinsip organisasi, dan memiliki keyakinan besar atas organisasi dan ingin tetap ada serta bertahan didalam organisasi. Komitmen organisasi penting untuk diteliti, karena komitmen dapat mempengaruhi keberhasilan organisasi dalam jangka panjang. Menurut Mowday et al. (1979) komitmen organisasi merupakan keyakinan dan dukungan yang kuat terhadap nilai dan sasaran (goal) yang ingin dicapai organisaasi.

Gaya kepemimpinan adalah pola tingkah laku yang dirancang sedemikian rupa untuk mempengaruhi bawahannya agar dapat memaksimalkan kinerja yang dimiliki bawahannya sehingga kinerja organisasi dan tujuan organisasi dapat dimaksimalkan. Seorang pemimpin harus menerapkan gaya kepemimpinan untuk mengelola bawahannya, karena seorang pemimpin akan sangat mempengaruhi keberhasilan organisasi dalam mencapai tujuannya 
(Waridin \& Guritno, 2005). Kepemimpinan transformasional seperti yang diuraikan oleh Northouse (2013) merupakan sebuah gaya kepemimpinan yang menekankan pada proses dimana orang terlibat dengan orang lain dan menciptakan suatu hubungan yang meningkatkan motivasi baik dalam diri pemimpin maupun pengikutnya. Pemimpin yang menggunakan gaya kepemimpinan transformasional cenderung memberi perhatian lebih kepada para pengikutnya.

Sebagaimana yang diungkapkan Robbins (2006) bahwa dewasa ini banyak organisasi-organisasi yang mencari pemimpin yang dapat menerapkan kepemimpinan transaksional dan transformasional dalam suatu organisasi. Kepemimpinan transformasional inilah yang sungguh-sungguh diartikan sebagai kepemimpinan yang sejati karena kepemimpinan ini bekerja menuju sasaran pada tindakan mengarah organisasi kepada suatu tujuan yang tidak pernah diraih sebelumnya. Para pemimpin secara riil harus mampu mengarahkan organisasi menuju arah baru. Dimana dalam kepemimpinan transformasional ini dibutuhkan tindakan memotivasi dari pimpinan, agar dapat mencapai tujuan yang diharapkan. Lebih lanjut Sarros \& Butchatsky (1996) menjelaskan bahwa model kepemimpinan transformasional merupakan konsep kepemimpinan yang terbaik dalam menguraikan karakteristik pemimpin sehingga para pemimpin kita lebih berkerakyatan dan berkeadilan sosial.

Mangkunegara (2005) menyatakan istilah kinerja berarti job performance (prestasi kerja) yaitu pegawai dalam melaksanakan tugasnya sesuai dengan tanggung jawab yang diberikan kepadanya memperoleh hasil kerja secara kualitas dan kuantitas. Kemudian Dharma (1985) menyatakan bahwa kinerja (performance) adalah susuatu yang dikerjakan, produk atau jasa yang dihasilkan atau yang diberikan seseorang atau sekelompok orang. Suatu metode atau pendekatan dapat dilakukan untuk mengukur kinerja. (Hirsch \& Boal (1994), Kaplan \& Norton (2000), Lau \& Sholihin (2005), Pratolo (2007) menyatakan pengukuran kinerja terdiri atas pengukuran kinerja non keuangan (non financial performace measurement) dan pengukuran kinerja keuangan (financial performance measurement).

Setyawan \& Putri (2013) melakukan penelitian dengan judul "Pengaruh Good Corporate Governance Terhadap Kinerja Keuangan Lembaga Perkreditan Desa (LPD) di Kecamatan Mengwi Kabupaten Badung" bertujuan untuk mengetahui pengaruh Good Corporate Governance terhadap kinerja keuangan Lembaga Perkreditan Desa di Kabupaten Badung. Metode pengumpulan data menggunakan teknik kuesioner. Sampel dalam penelitian tersebut berjumlah 35 LPD di Kecamatan Mengwi Kabupaten Badung dengan teknik sampel jenuh.Teknik analisis data yang digunakan adalah analisis regresi linier sederhana. Hasil dari pengujian hipotesis adalah Good Corporate Governance berpengaruh positif dan signifikan terhadap kinerja keuangan LPD di Kecamatan Mengwi Kabupaten Badung.

$\mathrm{H}_{1}$ : Penerapan Good Corporate Governance berpengaruh positif terhadap kinerja karyawan Lpd di Kabupaten Badung.

Komitmen organisasi merupakan dorongan dari dalam individu untuk melakukan sesuatu agar dapat menunjang keberhasilan organisasi sesuai dengan tujuan yang telah ditetapkan dan lebih mengutamakan kepentingan organisasi. 
Karyawan atau anggota organisasi yang memiliki komitmen yang kuat akan bekerja dengan maksimal agar organisasi tempat mereka bekerja dapat mencapai keberhasilan bekerja dengan maksimal. Desmiyawati \& Witaliza (2012) dalam penelitiannya "Pengaruh Komitmen Organisasi, Pengendalian Intern, dan Akuntabilitas Publik Terhadap Kinerja Organisasi (Studi Empiris pada Rumah Sakit Swasta di Provinsi Riau)", menyimpulkan bahwa komitmen organisasi berpengaruh terhadap kinerja dengan akuntabilitas publik sebagai variabel intervening. Berdasarkan konsep dan bukti empiris yang diperoleh dari penelitian sebelumnya, maka hipotesis pertama yang diajukan adalah sebagai berikut.

$\mathrm{H}_{2}$ : Komitmen Organisasi berpengaruh positif terhadap kinerja karyawan LPD di Kabupaten Badung.

Gaya kepemimpinan merupakan norma perilaku yang digunakan seorang manajer pada saat ia mempengaruhi perilaku bawahannya. Seseorang yang menjalankan fungsi manajemen berkewajiban mengarahkan karyawan yang dibawahnya agar mereka tetap melaksanakan tugas dengan baik, memiliki dedikasi terhadap organisasi dan tetap merasa berkewajiban untuk mencapai tujuan organisasi (Sedarmayanti, 2007). Jika kepemimpinan tersebut terjadi pada suatu organisasi formal tertentu, di mana para manajer perlu mengembangkan karyawan, membangun iklim motivasi, menjalankan fungsi-fungsi manajerial dalam rangka menghasilkan kinerja yang tinggi dan meningkatkan kinerja, maka manajer perlu menyesuaikan gaya kepemimpinannya.

Trijayanti (2015) dalam penelitian Pengaruh Gaya Kepemimpinan, Kepuasan Kerja, dan Motivasi Kerja terhadap Kinerja Auditor (Studi Empiris pada Kantor Akuntan Publik (KAP) di Provinsi Bali) menyatakan bahwa gaya kepemimpinan berpengaruh positif terhadap kinerja seorang auditor. Berdasarkan konsep dan bukti empiris yang diperoleh dari penelitian sebelumnya, maka hipotesis yang diajukan adalah sebagai berikut.

$\mathrm{H}_{3}$ : Gaya kepemimpinan transformasional berpengaruh secara positif terhadap kinerja karyawan LPD di Kabupaten Badung.

\section{METODE PENELITIAN}

Memberikan kuesioner. Populasi dalam penelitian ini adalah semua LPD Kabupaten Badung. Dimana Kabupaten Badung terdiri dari 122 LPD yang terdiri dari 989 kariyawan

Teknik penentuan sampel dalam penelitian ini adalah teknik slovin, dengan tujuan untuk memperoleh sampel yang representatif dengan melihat populasi LPD yang ada di Kabupaten Badung yang berstrata, yakni terdiri beberapa Kecamatan, sehingga peneliti mengambil sampel dari 6 Kecamatan dan masing masing Kecamatan diambil beberapa LPD sebagai sampel. Oleh karena populasi dianggap berukuran besar (lebih dari 100) maka pengambilan sampel menggunakan metode Slovin dengan rumus (Wirawan, 2014).

$$
\begin{aligned}
& n=\frac{N}{1+N e^{2}} \\
& \begin{array}{l}
\text { Keterangan: } \\
\mathrm{n}=\text { Sampel } \\
\mathrm{N}=\text { Populasi }
\end{array}
\end{aligned}
$$




$$
\begin{aligned}
& \mathrm{e}=\text { Tingkat kesalahan } \\
& N=\frac{122}{1+\left(122 \times 0,1^{2}\right)} \\
& =54 \frac{6100}{111} \\
& \quad N=54.954(\text { dibulatkan 55) }
\end{aligned}
$$

Berdasarkan hasil perhitungan sampel, diperoleh sampel sebanyak 55 LPD. Responden yang dipilih dalam penelitian ini adalah orang-orang yang mengetahui wewenang dan tugas pengelolaan LPD dan fungsi-fungsi badan pengawas dalam menilai peranan good corporate governance, komitmen organisasi, gaya kepemimpinan transformasional dan kinerja karyawan selama tahun 2018. Berdasarkan kriteria yang ditetapkan maka sampel diambil sebanyak 55 LPD di Kabupaten Badung. Tiap-tiap LPD diambil dua responden bendahara dan tata usaha sehingga total responden berjumlah 110 orang. Bendahara dan tata usaha digunakan sebagai responden karena paling berperan dalam pengaruh penerapan good corporate governance, komitmen organisasi dan gaya kepemimpinan transformasional di LPD.

Mengetahui pengaruh good corporate governance, komitmen organisasi, gaya kepemimpinan transformasional pada kinerja Lembaga Perkreditan Desa di Kabupaten Badung menggunakan variabel analisis regresi linear berganda. Secara umum formulasi dari regresi linear berganda dapat disajikan sebagai berikut:

$$
\begin{aligned}
& Y=\alpha+\beta_{1} X_{1}+\beta_{2} X_{2}+\beta_{3} X_{3}+\varepsilon \\
& \text { Keterangan: } \\
& \mathrm{Y} \quad=\text { kinerja Lembaga Perkreditan Desa } \\
& \text { a } \quad=\text { konstanta } \\
& \beta_{1,2,3,4}=\text { koefisien regresi dari variabel independen } \\
& \varepsilon=\text { error term } \\
& \mathrm{X}_{1} \quad=\text { good corporate governance } \\
& \mathrm{X}_{2} \quad=\text { komitmen organisasi } \\
& \mathrm{X}_{3} \quad=\text { gaya kepemimpinan transformasional }
\end{aligned}
$$

\section{HASIL DAN PEMBAHASAN}

Statistik deskriptif dalam penelitian ini diujikan untuk memberikan informasi tentang karakteristik variabel penelitian. Nilai minimum menunjukkan nilai terkecil atau terendah pada suatu gugus data. Nilai maksimum menunjukkan nilai terbesar atau tertinggi pada suatu gugus data. Rata-rata (mean) merupakan cara yang paling umum digunakan untuk mengukur nilai sentral dari suatu distribusi data yang diteliti. Hasil dari deskriptif tersebut dapat dilihat pada Tabel 1, berikut.

Tabel 1. Hasil Statistik Deskriptif

\begin{tabular}{llllll}
\hline Variabel & $\mathrm{N}$ & \multicolumn{1}{c}{ Minimum } & \multicolumn{1}{c}{ Maximum } & Mean & \multicolumn{1}{c}{ Std. Deviation } \\
\hline GCG $(\mathrm{X})$ & 110 & 36,00 & 81,00 & 59,07 & 10,723 \\
KO $(\mathrm{X} 2)$ & 110 & 6,00 & 30,00 & 21,59 & 4,901 \\
GKT $(\mathrm{X})$ & 110 & 6,00 & 19,00 & 12,17 & 3,074 \\
KK $(\mathrm{Y})$ & 110 & 8,00 & 23,00 & 15,72 & 3,584 \\
\hline
\end{tabular}

Sumber: Data Penelitian, 2020 
Berdasarkan Tabel 1, GCG memproleh nilai minimum dan maksimum sebesar 36.00 dan 81.00. Rata-rata sebesar 59,07 dan standar deviasi sebesar 10.723. Nilai rata-rata sebesar 59,07 menunjukkan secara rata-rata jawaban responden mengarah ke nilai maksimum yang artinya Good Corporate Governance cukup tinggi. Komitmen organisasi memperoleh nilai minimum dan maksimum sebesar 6.00 dan 30.00. Rata-rata sebesar 21.59 dan standar deviasi sebesar 4.901. Nilai rata-rata sebesar 21.59 menunjukkan secara rata-rata jawaban responden mengarah ke nilai maksimum yang artinya Komitmen Organisasi cukup tinggi. Gaya kepemimpinan transformal memperoleh nilai minimum dan maksimum sebesar 6.00 dan 19.00. Rata-rata sebesar 12.17 dan standar deviasi sebesar 3.074. Nilai rata-rata sebesar 12.17 menunjukkan secara rata-rata jawaban responden mengarah ke nilai maksimum yang artinya Gaya Kepemimpinan Transformasional cukup tinggi dan yang terakhir kinerja karyawan LPD di Kabupaten Badung memperoleh nilai minimum dan maksimum sebesar 8.00 dan 23.00. Rata-rata sebesar 15.72 dan standar deviasi sebesar 3.584. Nilai rata-rata sebesar 15.72 menunjukkan secara rata-rata jawaban responden mengarah ke nilai maksimum yang artinya Kinerja Karyawan LPD di Kabupaten Badung cukup tinggi.

Tabel 2. Hasil Analisis Regresi Linier Berganda

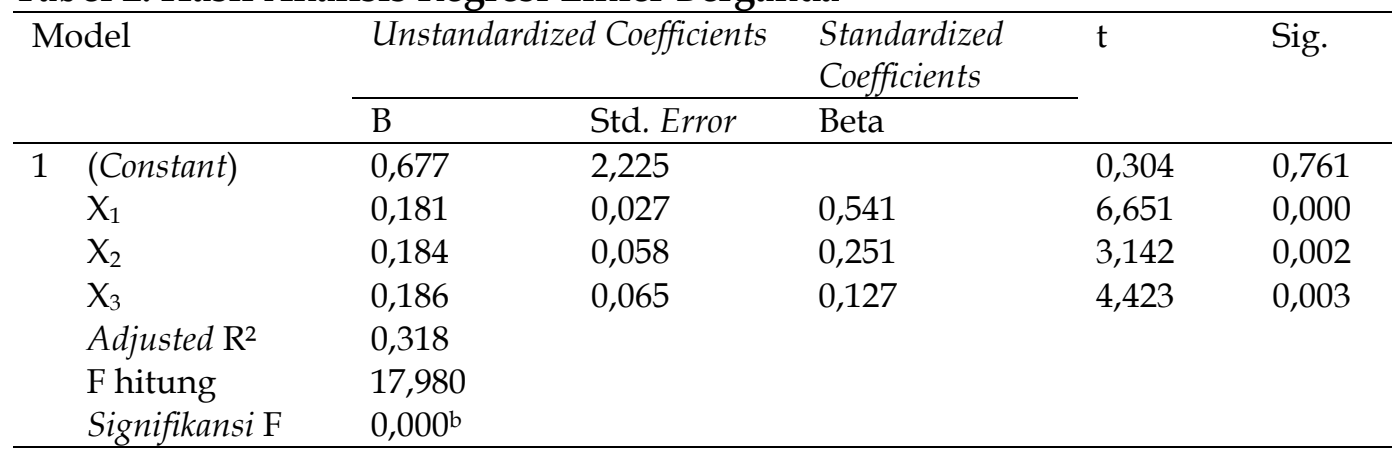

Sumber: Data Penelitian, 2020

Berdasarkan hasil analisis regresi linear berganda pada Tabel 2, maka dapat dirumuskan persamaan regresinya sebagai berikut:

$$
\mathrm{Y}=0.677+0.181 \mathrm{X} 1+0.184 \mathrm{X} 2+0.186 \mathrm{X} 3
$$

Nilai konstanta sebesar 0,677. Ini berarti apabila variabel Good Corporate Governance, Komitmen Organisasi dan Gaya Kepemimpinan Transformasional bernilai nol, maka Kinerja Karyawan LPD di Kabupaten Badung meningkat sebesar 0,677 satuan.

Nilai koefisien regresi dari Good Corporate Governance sebesar 0,181 menunjukkan bahwa variabel Good Corporate Governance mempunyai pengaruh positif pada Kinerja Karyawan LPD di Kabupaten Badung sebesar 0,181. Ini berarti apabila Good Corporate Governance naik sebesar 1 satuan dengan anggapan bahwa variabel bebas lainnya konstan, maka Kinerja Karyawan LPD di Kabupaten Badung akan mengalami peningkatan sebesar 0,181 satuan.

Nilai koefisien regresi dari Komitmen Organisasi sebesar 0,184 menunjukan bahwa Komitmen Organisasi mempunyai pengaruh positif pada Kinerja Karyawan LPD di Kabupaten Badung sebesar 0,364. Ini berarti apabila Komitmen Organisasi naik sebesar 1 satuan dengan anggapan bahwa variabel 
bebas lainnya konstan, maka Kinerja Karyawan LPD di Kabupaten Badung akan mengalami peningkatan sebesar 0,184 satuan.

Nilai koefisien regresi dari Gaya Kepemimpinan Transformasional sebesar 0,186 menunjukan bahwa variabel Gaya Kepemimpinan Transformasional mempunyai pengaruh positif pada Kinerja Karyawan LPD di Kabupaten Badung sebesar 0,186. Ini berarti apabila Gaya Kepemimpinan Transformasional naik sebesar 1 satuan dengan anggapan bahwa variabel bebas lainnya konstan, maka Kinerja Karyawan LPD di Kabupaten Badung akan mengalami peningkatan sebesar 0,186 satuan.

Uji F dilakukan dengan melihat nilai signifikasi pada tabel Annova dengan bantuan program SPSS yaitu dengan membandingkan tingkat signifikasi variabel bebas dengan $\alpha=0,05$. Apabila tingkat signifikansi $\mathrm{F}<\alpha=0,05$ maka $_{0}$ ditolak, dan sebaliknya jika tingkat signifikansi $\mathrm{F} \geq a=0,05$ maka $\mathrm{H}_{0}$ diterima. Hasil uji kelayakan model (uji F) akan disajikan dalam Tabel 3, sebagai berikut.

\section{Tabel 3. Hasil Uji F}

\begin{tabular}{llllll}
\hline Model & Sum of square & Df & Mean Square & F & Sig. \\
\hline Regression & 472,243 & 3 & 157,414 & 17,980 & $0,000 \mathrm{~b}$ \\
Residual & 928,021 & 106 & 8,755 & & \\
Total & 1400,264 & 109 & & & \\
\hline
\end{tabular}

Sumber: Data Penelitian, 2020

Dari hasil $\mathrm{F}$ test didapatkan hasil bahwa nilai $\mathrm{F}$ sebesar 17,980 dengan tingkat signifikansi 0,000. Karena tingkat signifikansi 0,000 lebih kecil dari 0,05 maka ini berarti bahwa model regresi yang digunakan layak dapat digunakan untuk memprediksi variabel independenden atau dapat dikatakan bahwa Good Corporate Governance, Komitmen Organisasi dan Gaya Kepemimpinan Transformasional secara bersama-sama berpengaruh terhadap Kinerja Karyawan LPD di Kabupaten Badung.

Uji t digunakan untuk mengetahui pengaruh variabel bebas pada variabel terikat secara parsial. Dari hasil uji diperoleh data seperti pada Tabel 4.

Tabel 4. Hasil Uji t

\begin{tabular}{llllll}
\hline Model & $\begin{array}{l}\text { Unstandardized } \\
\text { Coefficients }\end{array}$ & & $\begin{array}{l}\text { Standardized } \\
\text { Coeficient }\end{array}$ & T & Sig. \\
\cline { 2 - 4 } & $\mathrm{B}$ & Std. Error & Beta & & \\
\hline (Constant) & 0,677 & 2,225 & & 0,304 & 0,761 \\
X1 & 0,181 & 0,027 & 0,541 & 6,651 & 0,000 \\
X2 & 0,184 & 0,058 & 0,251 & 3,142 & 0,002 \\
X3 & 0,186 & 0,065 & 0,127 & 4,423 & 0,003 \\
\hline
\end{tabular}

Sumber: Data Penelitian, 2020

Berdasarkan hasil pengujian yang diperoleh dari Tabel 4, menunjukkan bahwa tingkat signifikansi Good Corporate Governance sebesar 0,000 lebih kecil dari nilai $\mathrm{a}=0,05$ dan nilai koefisien regresi dari Good Corporate Governance sebesar 0.181 menunjukkan bahwa variabel Good Corporate Governance mempunyai pengaruh positif pada Kinerja Karyawan LPD di Kabupaten Badung. Hal ini menunjukkan bahwa hipotesis pertama $\left(\mathrm{H}_{1}\right)$ diterima yaitu, Good Corporate Governance berpengaruh positif pada Kinerja Karyawan LPD di Kabupaten Badung yang berarti adanya hubungan yang searah antara Good Corporate Governance pada Kinerja Karyawan LPD di Kabupaten Badung. Jika Good Corporate Governance semakin tinggi, maka tingkat Kinerja Karyawan LPD 
di Kabupaten Badung juga semakin tinggi. Hasil penelitian ini sesuai dengan hasil penelitian terdahuu yang dilakukan oleh Setyawan dan Putri (2013) dengan judul "Pengaruh Good Corporate Governance Terhadap Kinerja Lembaga Perkreditan Desa (LPD) di Kecamatan Mengwi Kabupaten Badung", menyimpulkan bahwa good corporate governance berpengaruh terhadap kinerja Lembaga Perkreditan Desa (LPD) di Kecamatan Mengwi Kabupaten Badung.

Berdasarkan hasil pengujian yang diperoleh dari Tabel 4, menunjukkan bahwa tingkat signifikansi Komitmen Organisasi sebesar 0,000 lebih kecil dari nilai $\mathrm{a}=0,05$ dan nilai koefisien regresi dari Komitmen Organisasi sebesar 0.184 menunjukkan bahwa variabel Komitmen Organisasi mempunyai pengaruh positif pada Kinerja Karyawan LPD di Kabupaten Badung. Hal ini menunjukkan bahwa hipotesis kedua $\left(\mathrm{H}_{2}\right)$ diterima yaitu, Komitmen Organisasi berpengaruh positif pada Kinerja Karyawan LPD di Kabupaten Badung yang berarti adanya hubungan yang searah antara Komitmen Organisasi pada Kinerja Karyawan LPD di Kabupaten Badung. Jika Komitmen Organisasi semakin tinggi, maka tingkat Kinerja Karyawan LPD di Kabupaten Badung juga semakin tinggi. Hasil penelitian ini sesuai dengan hasil penelitian terdahuu yang dilakukan oleh Desmiyawati \& Witaliza (2012) dalam penelitiannya "Pengaruh Komitmen Organisasi, Pengendalian Intern, dan Akuntabilitas Publik Terhadap Kinerja Organisasi (Studi Empiris pada Rumah Sakit Swasta di Provinsi Riau)", menyimpulkan bahwa komitmen organisasi berpengaruh terhadap kinerja dengan akuntabilitas publik sebagai variabel intervening.

Berdasarkan hasil pengujian yang diperoleh dari Tabel 4, menunjukkan bahwa tingkat signifikansi Gaya Kepemimpinan Transformasional sebesar 0,187 lebih kecil dari nilai a = 0,05 dan nilai koefisien regresi dari Gaya Kepemimpinan Transformasional sebesar 0.003 menunjukkan bahwa variabel Gaya Kepemimpinan Transformasional mempunyai pengaruh positif pada Kinerja Karyawan LPD di Kabupaten Badung. Hal ini menunjukkan bahwa hipotesis ketiga $\left(\mathrm{H}_{3}\right)$ diterima yaitu, Gaya Kepemimpinan Transformasional berpengaruh pada Kinerja Karyawan LPD di Kabupaten Badung yang berarti adanya pengaruh signifikan Gaya Kepemimpinan Transformasional pada Kinerja Karyawan LPD di Kabupaten Badung. Gaya Kepemimpinan Transformasional berpengaruh positif pada Kinerja Karyawan LPD di Kabupaten Badung yang artinya semakin tinggi Gaya Kepemimpinan Transformasional, maka tingkat Kinerja Karyawan LPD di Kabupaten Badung juga semakin tinggi. Hasil penelitian ini sesuai dengan hasil penelitian terdahuu yang dilakukan oleh Trijayanti (2015) dengan judul "Pengaruh Gaya Kepemimpinan, Kepuasan Kerja, dan Motivasi Kerja terhadap Kinerja Auditor (Studi Empiris pada Kantor Akuntan Publik (KAP) di Provinsi Bali)", yang menyatakan bahwa gaya kepemimpinan berpengaruh positif terhadap kinerja seorang auditor.

Koefisien determinasi mengukur seberapa jauh kemampuan model dalam menerangkan variasi variabel dependen (Ghozali, 2016). Nilai dari koefisien determinasi antara 0 sampai dengan 1 . Nilai koefisien determinasi yang kecil berarti kemampuan variabel independen dalam menjelaskan variasi variabel dependen amat terbatas, namun apabila nilai koefisien determinasi tinggi atau mendekati atau sama dengan 1 berarti variabel independen mampu 
sepenuhnya menjelaskan variabel dependen. Hasil uji koefisien determinasi dalam penelitian ini disajikan dalam Tabel 5 sebagai berikut:

Tabel 5. Hasil Uji Koefisien Determinasi

\begin{tabular}{|c|c|c|c|c|}
\hline Model & $\mathrm{R}$ & R Square & Adjusted R Square & Std. Error of the Estimate \\
\hline 1 & $0,581 \mathrm{a}$ & 0,337 & 0,318 & 2,959 \\
\hline
\end{tabular}
menunjukkan bahwa nilai Adjusted $R$ Square sebesar 0,318 mempunyai arti bahwa 31,8 persen variasi Kinerja Karyawan LPD di Kabupaten Badung dipengaruhi oleh variasi Good Corporate Governance, Komitmen Organisasi dan Gaya Kepemimpinan Transformasional, sedangkan sisanya sebesar 68,2 persen dipengaruhi oleh faktor lain yang tidak dimasukkan dalam model penelitian.

\section{SIMPULAN}

Simpulan yang dapat ditarik dalam penelitian ini adalah penelitian ini dapat memberikan bukti empiris tentang good corporate governance, komitmen organisasi dan gaya kepemimpinan transformasional pada kinerja karyawan LPD di Kabupaten Badung. Disamping itu, pada penelitian ini dijadikan sebagai sarana dalam menerapkan dan mempraktekan ilmu pengetahuan yang diperoleh selama duduk dibangku kuliah dan membandingkannya dengan keadaan di lapangan. Bagi pihak Lembaga Perkreditan Desa (LPD) di Kabupaten Badung, hasil penelitian ini dapat memberikan manfaat sebagai masukan dalam pertimbangan pengambilan keputusan tentang good corporate governance, komitmen organisasi dan gaya kepemimpinan transformasional. Bagi peneliti lain dapat digunakan sebagai bahan referensi dan inspirasi dalam melakukan penelitian selanjutnya. Selain itu penelitian ini dapat memperluas wawasan pengetahuan.

\section{REFERENSI}

Andriyanto, N. (2013). Good e-governance: Transparansi dan Akuntabilitas Publik melalui e-Government. Malang: Bayumedia Publishing.

Bali.bps.go.id.

Banyaknya

BPR LPN/LPK/BKPD/BUKP/KURK/LPD/BPR lainnya. Https://Bali.Bps.Go.Id/.

Desmiyawati, \& Witaliza, W. (2012). Pengaruh Komitmen Organisasi Pengendalian Intern dan Akuntabilitas Publik Terhadap Kinerja Organisasi. Pekbis Jurnal, 4(1).

Dewi, K. K. (2014). Pengaruh Penerapan Prinsip-Prinsip Good Corporate Governance Pada Kinerja Keuangan Lembaga Perkreditan Desa Kabupaten Gianyar. Universitas Udayana.

Dharma, A. (1985). Manajemen Personalia. Jakarta: Ghalia Indonesia.

Ghozali, H. I. (2016). Aplikasi Analisis Multivariate dengan Program IBM SPSS 21. Semarang: Universitas Diponegoro.

Ghozali, I. (2016). Aplikasi Analisis Multivariete Dengan Program IBM SPSS 23 (8th ed.). Semarang: Badan Penerbit Universitas Diponegoro.

Hirsch, P. M., \& Boal, K. B. (1994). Statement from New Editors. Journal of Management https://doi.org/https://doi.org/10.1177/105649269431007 
Kaplan, R. S., \& Norton, D. P. (2000). The Balance Scorecard: Menerapkan Strategi Menjadi Aksi. Boston: Harvard Business School Press.

Karim, F., \& Rehman, O. (2012). Impact Of Job Satisfaction , Perceived Organizational Justice and Employee Empowerment on Organizational Commitment in Semi-Government Organizations of Pakistan. Journal of Business Studies Quarterly, 3(4).

Lau, C. M., \& Sholihin. (2005). Financial and nonfinancial performance measures: How do they affect job satisfaction? Departement of accounting and finance, UW Business School. The University of Western Australia.

Mangkunegara, A. A. A. P. (2005). Manajemen Sumber Daya Manusia Perusahaan. Bandung: PT. Remaja Rosda Karya.

Mowday, R. T., Steers, R. M., \& Porter, L. W. (1979). The measurement of organizational commitment. Journal of Vocational Behavior, 14(2), 224-247. https://doi.org/https:/ / doi.org/10.1016/0001-8791(79)90072-1

Northouse, P. G. (2013). Kepemimpinan. Jakarta: PT Indeks Kelompok Gramedia.

Pratolo, S. (2007). Good Corporate Governance dan Penerapannya di Indonesia. Jurnal Manajemen Dan Kewirausahaan, 8(1), 1-9.

Ristanti, N. M. A. (2014). Pengaruh System Pengendalian Intern Pengelola Keuangan Daerah dan Komitmen Organisasi Terhadap Penerapan Good Corporate Governance Pada Satuan Kerja Perangkat Daerah Kabupaten Tabanan. Jurnal Akuntansi, 2(1).

Robbins, S. P. (2006). Prinsip-prinsip Perilaku Organisasi (Kesepuluh). Jakarta: PT Indeks Kelompok Gramedia.

Robbins, S. P., \& Judge. (2007). Perilaku Organisasi. Jakarta: Salemba Empat.

Sarros, J. C., \& Butchatsky, O. (1996). Leadership. Australia's Top CEOs: Finding. Out What Makes Them the Best. Sydney: Harper Business.

Sedarmayanti. (2007). Sumber Daya Manusia dan Produktivitas Kerja. Bandung: Penerbit Mandar Maju.

Setyawan, K. M., \& Putri, I. G. A. M. A. D. (2013). Pengaruh Good Corporate Governance Terhadap Kinerja Keuangan Lembaga Pekreditan Desa Di Kecamatan Mengwi Kabupaten Badung. E-Jurnal Akuntansi, 5(3), 586-598.

Shore, L. M., \& Wayne, S. J. (1993). Commitment and employee behavior: Comparison of affective commitment and continuance commitment with perceived organizational support. Journal of Applied Psychology, 78(5), 774780.

Surya, I., \& Yustiavandana, I. (2006). Penerapan Good Governance: Mengesampikan Hak Istimewa Demi Kelangsungan Usaha. Jakarta: Prenada Media Grup.

Trijayanti, K. A. (2015). Pengaruh Gaya Kepemimpinan, Kepuasan Kerja, dan Motivasi Kerja Terhadap Kinerja Auditor. E-Journal Undiksha, 3(1).

Waridin, \& Guritno, B. (2005). Pengaruh Persepsi Karyawan Mengenai Perilaku Kepemimpinan, Kepuasan Kerja Dan Motivasi Terhadap Kinerja. JRBI, 1(1).

Wiratno, A. (2013). Pengaruh Budaya Organisasi, Gaya Kepemimpinan, Komitmen Organisasi dan Pengendalian Intern Terhadap Penerapan Good Governance Serta Implikasi Paa Kinerja. Journal Dan Proceeding Feb Unsoed, 1(1).

Wirawan. (2014). Kepemimpinan: Teori Psikologi, Perilaku Organisasi, Aplikasi dan Penelitian. Jakarta: Rajawali Pers. 